\title{
MJN COMMUNITY NURSING A TOOL FOR ACHIEVING SDG AND UHC TARGETS IN NIGERIA
}

\author{
Abdullahi Dahiru' ${ }^{12 *}$, Rabiu Musa ${ }^{3}$, Salisu Muhammad Jella² \\ ${ }^{1}$ Lincoln University College Malaysia/College of Nursing and Midwifery, School of Nursing Kano Nigeria \\ ${ }^{2}$ College of Nursing and Midwifery, Umar Ringim School of Postbasic Anaesthesia Nursing Kano Nigeria \\ ${ }^{3}$ College of Nursing and Midwifery, School of Nursing Kano Nigeria \\ *Corresponding Author's Email: abdullahidahiru84@gmail.com
}

\begin{abstract}
This paper explores community Nursing programme as a tool for the targets in Nigeria. About $70 \%$ of Nigerian lives in the rural communities and lack access to healthcare. Reviewed literature identified community health problems to include maternal and neonatal morbidity and mortality, communicable and non-communicable diseases. The Licensed Community Nurses will no doubt mitigate gross shortage to enable rural communities' access health care. The paper describes the distribution of nurses in Nigeria, trends in illness. The study concludes that Community Nursing is critical for improving community's health.
\end{abstract}

Keywords: Community Nursing, Universal Health Coverage, Nursing and Midwifery Council

\section{INTRODUCTION}

COVID-19 pandemic further exacerbates the global health crisis whose impact will no doubt be felt at the community level where majority of people live (Aluko, Anthea \& Marie Modeste, 2019; Efe, 2013). The World Health Organization (WHO, 2010) said that a careful look at the Nigeria's health care system shows that there is a need for additional human resource for health such as nurses. Similarly, International Council for Nurses (ICN) and WHO (2020) observed that there is need for the increase in nursing workforce (Gulf News, 2020).

In order to scale up and check this gross shortage, Nursing and Midwifery Council of Nigeria (NMCN) regulatory body for training of professional of nurses and midwives in Nigeria expressed the same concern and swiftly issued a recent circular mandating school's to run a two years community nursing programme. The body said that being aware of the gross shortage of human resources for health at the community level occasioned by mass migration of Nurses to urban areas and other countries have resulted in weakening of the primary health care system and poor access to health care by rural dwellers in the country this circular have been waded in (NMCN, 2020).

The council explained that it is done in order to close this critical gap and to further accelerate the achievement of the Sustainable Development Goals (SDG) targets Universal Health Coverage (UHC) in Nigeria, they are introducing Community Nursing Programme to meet the health care needs of rural areas of Nigeria where it is hard to reach (NMCN, 2020).

\section{The distribution of nurses in Nigerian}

Recent literature reviewed showed that the population distribution per nurse which stood at 920 in 2000 increased relatively to 1,179 in 2005 and 1,405 in 2007. There is annual positive increase in the number of the persons per nurse, implying reduced accessed of the citizens to the services of nurses. The data suggest a higher growth rate of population than the number of nurses (Nigeria's Social Indicators for Policy and Legislative Guide, 2010). The World Health Organization and the International Council for Nurses recommended among others that there must be a increase in production of more nurses (Gulf News, 2020).

\section{Licensed Community Nurse (LCN)}

One of the strategies designed by the NMCN to accelerate the progress towards the mitigation of this serious community health gap is the Licensed Community Nurse (LCN) programme. The LCN programme is designed to produce competent lower cadre nursing practitioners who would be at the 
forefront successfully implement nursing and health care services at grass root level toward meeting the health care needs of the rural areas and other areas which are hard to reach communities in Nigeria.

Therefore, according to the council the requirements for admission into the LCN programme must at least include Biology, English language and any other two subject at not more than two sitting at the West African Examination Council (WAEC) and or the National Common Examination (NECO). The candidate upon the successful completion of the two-year Community Nursing Programme, shall be registered as a 'Licensed Community Nurse (LCN)' by the Nursing and Midwifery Council of Nigeria to practice as a Community Nurse in homes, Primary Health care Centres and communities in Nigeria. The LCN will enjoy career progression similar to that enjoyed by licensed community midwife (NMCN, 2020).

\section{Trends in illness and diseases}

Health experts such as Kabir (2015); Oyerinde, (2019); Suleiman, (2018) reported that there is demands for increased nursing care at all levels. For instance, the rise in number of communicable diseases (NCDs) such as cholera, TB, malaria, Hepatitis A, and sexually transmitted infections and non-communicable diseases such as hypertension, diabetes mellitus, strokes, arthritis and other age-related degenerative diseases (Dahiru, 2019; Starfield \& Macinko, 2005).

\section{The Demand for Community Nursing Care}

There are population disparities, the need for blood pressure screenings, wounds care and optimization of rural community's wellbeing. This called for the commencement of specialized form of nursing specialty to look after the nursing care needs of the rural communities; this would mitigate the nursing shortage at the rural community level. Therefore, substantial body of literature documented some of the responsibilities of community nurse at the primary health care level as counselors, clinicians, educators, researchers, advocators, collaborators, and consultants. For instance, some studies (Blackie \& Appleby, 2000; Kotrotsiou et al., 2008; Muhammad, 2018) explained that a trained, certified and licensed community nurse (CLN) would no doubt function effectively and efficiently in rendering of nursing care taking into considerations the community's resources and preferences.

The health demands at the community level revolves around four basic pivots (1) care of health problems and risks, (2) life styles issues such as sedentary behavior due to the lack of exercise and smoking, (3) encourage sanitation of houses, markets and schools within the community and (4) advocate to the government and private for the community wellbeing to provide and maintain health posts in communities (WHO, 2010). Thus, the Licensed Community Nurse is trained to tackle these community health problems as they emerged.

\section{CONCLUSION}

The changing nature of health dynamics inform the need to evolve, provide, approval for the successful taking up of community nursing in order to assist rural communities to access nursing care in Nigeria. It is recommended that public and private schools of nursing should avail themselves of this opportunity to contribute to the attainment of the achievement of targets among rural communities in Nigeria through commencement of the community nursing programme.

\section{Conflict of Interests}

The authors declare that they have no conflict of interest.

\section{ACKNOWLEDGEMENT}

The authors are thankful to the institutional authority for completion of the work.

\section{REFERENCES}

Aluko, A.O., Anthea, R. \& Marie Modeste, R.R. (2019). Manpower capacity and reasons for staff shortage in primary health care maternity centres in Nigeria: a mixed-methods study. BMC Health Services Research (2019), 19:10

Blackie, C \& Appleby, F.M. (2000). Community Health Care Nursing. Churchill Livingstone Harcourt Publishers Ltd.

Dahiru, A. (2019). Workers Health: Measures to Prevent Untimely Death. Paper presented at a West African Safety Week Seminar Organized by the Federal Road Safety Corps RS 1.24 Nassarawa Kano Unit Command, Kano state, Nigeria. 
Efe, S.I. (2013). Health care problem and management in Nigeria. Journal of Geography and Regional Planning, 6(6), pp 244-254.

Gulf News (2020). The World needs 5.9 million more nurses worldwide. Retrived from: gulfnews.com/world/whoneeds-5.9-million.more-nurses.

Kabir, M. (2015). Public Health Concern for Chronic Non-communicable Diseases Surpasses Anxiety over Most Infections. A Bayero University, Kano, Inaugural Professorial Lecture Series No. 17.

Kotrotsiou, S., Lavdaniti, M., Psychogiou, M., Paralikas, Th., Papathanasiou, I. \& Lahana E. (2008). Community nurses' role as counsellors in primary health care. International Journal of Caring Sciences, 1(2), pp 92-98.

Muhammad, M.S. (2019). The Role and Responsibilities of a Community Nurse. An unpublished paper presented at the Kano Nurses Study Circle.

Nigeria's Social Indicators for Policy and Legislative Guide (1999 - 2007) (2010). Population - Nurse Ratio. Policy Analysis and Research Project National Assembly Abuja, Nigeria. Edited Hamalai, L.

Nursing and Midwifery Council of Nigeria (NMCN) (2020). Introduction of Community Nursing Programme as a Modalities for Strengthening Human Resources at the Primary Health Care Level and Reduction of Maternal and Infant Mortality in Nigeria. N\&MCN/SG/RO/CIR/24/VOL.4/152 dated March 3, 2020.

Oyerinde, O.O. (2019). Man Does not Die but Kills Himself: The Dilemma of the Health Educator and the Moderating Influence of Health Education. A Bayero University, Kano, Inaugural Professorial Lecture Series No. 38.

Starfield, B. \& Macinko, J. (2005). Contribution of primary care to health systems and health. Milbank Quarterly, 2005(83), pp 457-502.

Suleiman, M.A. (2018). Health Education in contemporary Nigeria Health Problems. A Lead paper presented at the $23^{\text {rd }}$ Annual Conference of National Association of Health Educators (NAHE). The Theme: Health Education in Contemporary Nigerian Health Problems Held on Wednesday $27^{\text {th }}-$ Saturday $30^{\text {th }}$ at Bayero University, Kano, North west Nigeria.

World Health Organization (WHO) (2010). A framework for community health nursing education Nursing and Midwifery Unit World Health Organization, Regional Office for South-East Asia. Pdf.

World Health Organization (WHO) (2010). Global health workforce alliance country responses. Retrieved from: https:/www.who.int/workforcealliance/countries/nga/en/. 